\title{
DETERMINASI PERENCANAAN PENGANGGARAN DAN PENATAUSAHAAN KEUANGAN TERHADAP REALISASI PENYERAPAN ANGGARAN PADA DINAS PENDIDIKAN KOTA TANGERANG
}

\author{
${ }^{1}$ Edi Mulyadi \\ ${ }^{1}$ Universitas Islam Syekh-Yusuf, Tangerang \\ Email: edimulyadi@unis.ac.id
}

\begin{abstract}
Abstrak
Salah satu indikator penting untuk mengetahui kinerja APBN/APBD adalah tingkat penyerapan anggaran dalam pelaksanaannya. Penelitian ini dilakukan untuk menganalisis pengaruh perencanaan dan penatausahaan keuangan terhadap realisasi penyerapan anggaran pada Dinas Pendidikan dan Kebudayaan Kota Tangerang. Penelitian menggunakan metode deskriptif dengan pendekatan kuantitatif. Data dikumpulkan dengan menggunakan angket, obeservasi, dan studi dikumentasi. Teknik analisis data menggunakan model regresi linier berganda dengan bantuan program SPSS 20.

Hasil penelitian menunjukkan perencanaan dan penatausahaan keuangan berpengaruh signifikan terhadap realisasi penyerapan anggaran pada Dinas Pendidikan Kota Tangerang, dengan nilai koefisien korelasi positif kategori kategori sedang $(0,451)$, regresi linier berganda menunjukkan setiap kenaikan 1 satuan pada variabel perencanaan dan penatausahaan keuangan menyebabkan kenaikan terhadap realisasi penyerapan anggaran sebesar 25.530. Dari uji koefisien determinasi perencanaan dan penatausahaan keuangan memberikan kontribusi terhadap realisasi penyerapan anggaran sebesar $20.4 \%$, dan sisanya sebesar $79.6 \%$ merupakan pengaruh oleh faktor lain.
\end{abstract}

Kata kunci: perencanaan, penatausahaan keuangan, dan realisasi penyerapan anggaran. 


\section{A. Pendahuluan}

Dalam pengelolaan keuangan daerah, pengalokasian belanja modal sangat berkaitan dengan perencanaan keuangan jangka panjang, terutama pembiayaan untuk pemeliharaan aset tetap yang dihasilkan dari belanja modal tersebut. Dalam kaitan ini Dinas Pendidikan Kota Tangerang dalam melaksanakan tugas-tugas pemerintahan perlu merencanakan, melaksanakan dan mempertanggungjawabkan program / kegiatan dalam rangka melaksanakan tugas pokok dan fungsinya di bidang pendidikan.

Agar pelaksanaan anggaran dapat dipertanggungjawabkan dengan baik maka diperlukan suatu perencanaan yang matang dalam penyusunan anggaran di awal dan penatausahaan yang baik, karena sudah tidak dapat dipungkiri lagi bahwa lemahnya perencanaan di awal dan penatausahaan keuangan yang tidak efektif merupakan awal penyebab reendahnya realisasi penyerapan anggaran yang terjadi saat ini.

Sistem penyusunan anggaran seperti ini diakui menjadi salah satu persoalan yang melatarbelakangi kinerja penyerapan belanja rendah dan realisasi tidak maksimal.

Lemahnya perencanaan anggaran pada akhirnya akan memunculkan kemungkinan underfinancing atau overfinancing, yang kesemuanya mempengaruhi tingkat efisiensi dan efektivitas unit kerja pemerintah (Halim dkk. 2012: 141). Anggaran sebagai alat untuk melaksanakan strategi organisasi harus dipersiapkan sebaik-baiknya agar tidak terjadi bias atau penyimpangan.

Permasalahan yang dihadapi Dinas Pendidikan Kota Tangerang sebagaimana disebutkan pada laporan keuangan per 31 Desember 2017, seharusnya dana pendapatan maupun belanja daerah dapat lebih teralokasi dengan baik. Namun hal ini di Dinas Pendidikan belum tersosialisasi secara luas terutama berkaitan dengan realisasi APBD berbasis kinerja sebagai dasar dalam pelaksanaan penyusunan anggaran yang lebih transparan.

\section{B. Identifikasi dan Perumusan Masalah}

Permasalahan dalam penelitian ini dapat diidentifikasi sebagai berikut. Pada pangkalnya, minimnya pegawai yang memiliki kualifikasi tenaga ahli perencana dan pengelola keuangan merupakan salah satu kendala dalam proses penyerapan anggaran daerah. Selanjutnya penyebab rendahnya penyerapan anggaran di instansi Dinas Pendidikan juga terletak pada masih adanya rasa khawatir dari para pengguna anggaran. Aturan kebijakan pencairan dana APBD dianggap berbelit dan melalui proses Panjang. Secara intern rendahnya penyerapan anggaran disebabkan oleh lemahnya perencanaan awal terkait penganggaran atas kebutuhan, yang lebih buruk lagi, ini semua akibat tidak berdasarkan data yang valid sehingga terjadi silva pada akhir tahun. 
Dari identifikasi tersebut selanjutnya masalah dalam penelitian ini dibatasi dan dirumuskan sebagai berikut: "Sejauhmanakah determinasi perencanaan penganggaran dan penatausahaan keuangan terhadap penyerapan anggaran pada Dinas Pendidikan Kota Tangerang Tangerang?

\section{Metode Penelitian}

Penelitian menggunakan metode deskriptif dengan pendekatan kuantitatif. Sampel penelitian menggunakan sampel total yaitu sebanyak 78 orang pegawai yang ada pada Dinas Pendidikan Kota Tangerang. Data dikumpulkan dengan teknik utama berupa penyebaran angket. Selain itu dilakukan pula obeservasi dan penelaahan dokumen. Data dianalisis dengan uji regresi linier berganda dan uji korelasi.

\section{Kajian Pustaka, Kerangka Pemikiran, dan Hipotesis}

\section{Perencanaan Anggaran Daerah}

Keuangan daerah merupakan sub sistem dari keuangan negara. Ia merupakan bagian dari sistem keuangan negara dan merupakan elemen pokok dalam penyelenggaraan Pemerintah Daerah. Dari sisi pengeluaran, diberikannya kewenangan fiskal kepada sebuah daerah otonom didasarkan kepada prinsip agar alokasi sumber daya lebih efektif dan efisien. Selain itu juga Pemerintah Daerah lebih dekat ke masyarakat sehingga diasumsikan lebih mengetahui kebutuhan masyarakat. Dengan demikian alokasi sumber daya yang dilakukan oleh Pemerintah Daerah (Pemda) akan lebih responsif dalam menjawab kebutuhan masyarakat. Adapun dari sisi penerimaan, diberikannya kewenangan perpajakan kepada daerah dimaksudkan agar partisipasi masyarakat untuk mendanai pelayanan publik lebih tinggi karena masyarakat dapat merasakan langsung manfaat dari pembayaran pajak/retribusi tersebut.

Pengertian pernencanaan dikemukakan Azwar (2006: 5) dengan mengutif dan Peter F. Drucker. Menurut Billy E. Goetz perencanaan adalah kemampuan untuk memilih dari berbagai kemungkinan yang tersedia dan yang dipandang paling tepat untuk mencapai tujuan. Secara lebih komprehensif Drucker mengemukakan bahwa perencanaan adalah suatu proses kerja yang terus menerus yang meliputi pengambilan keputusan yang bersifat pokok dan penting dan yang akan dilaksanakan secara sistematik, melakukan perkiraan-perkiraan dengan mempergunakan segala pengetahuan yang ada tentang masa depan, mengorganisir secara sistematik segala upaya yang dipandang perlu untuk melaksanakan segala keputusan yang telah ditetapkan, serta mengukur keberhasilan dari pelaksanaan keputusan tersebut dengan membandingkan hasil yang dicapai terhadap target yang telah ditetapkan melalui pemanfaatan umpan balik yang diterima dan yang telah disusun secara teratur dan baik. 
Dengan demikian perencanaan adalah suatu proses menganalisis dan memahami sistem yang dianut, merumuskan tujuan umum dan tujuan khusus yang ingin dicapai, memperkirakan segala kemampuan yang dimiliki, menguraikan segala kemungkinan yang dapat dilakukan untuk mencapai tujuan yang telah ditetapkan, menganalisis efektivitas dari berbagai kemungkinan tersebut, menyusun perincian selengkapnya dari kemungkinan yang terpilih, serta mengikatnya dalam suatu sistem pengawasan yang terus menerus sehingga dapat dicapai hubungan yang optimal antara rencana yang dihasilkan dengan sistem yang dianut.

Proses perencanaan anggaran merupakan salah satu langkah penting dalam pengelolaan anggaran. Sejak dua belas bulan sebelum tahun anggaran dimulai, proses perencanaan anggaran sudah mulai berjalan (BPKP, 2012). Perencanaan dapat diartikan sebagai suatu proses untuk menentukan tindakan masa depan yang tepat, melalui urutan pilihan, dengan memperhitungkan sumber daya yang tersedia. Dalam konteks perencanaan pembangunan pemerintah, maka penyusunannya berpedoman pada Undang-Undang Nomor 25 Tahun 2004 tentang Sistem Perencanaan Pembangunan Nasional. Sedangkan penganggaran dapat diartikan sebagai suatu proses untuk menyusun sebuah anggaran, dan Anggaran Pendapatan dan Belanja Daerah (APBD) dapat diartikan sebagai rencana keuangan tahunan Pemerintah Daerah (Pemda) yang dibahas dan disetujui bersama oleh Pemerintah Daerah (Pemda) dan Dewan Perwakilan Rakyat Daerah (DPRD), dan ditetapkan dengan Peraturan Daerah (Perda), (Mulyana, 2010:12). Pelaksanaan anggaran merupakan tahapan pengelolaan keuangan yang harus dilaksanakan setelah proses perencanaan anggaran selesai. Pelaksanaan merupakan aktivitas atau usaha-usaha yang dilaksanakan untuk merealisasikan semua rencana dan kebijakan yang telah dirumuskan dan ditetapkan (BPKP, 2011). Pelaksanaan anggaran merupakan implementasi perencanaan anggaran yang telah disusun. Proses pelaksanaan anggaran meliputi persoalan-persoalan yang terjadi dalam internal satuan kerja, serta proses mekanisme pembayaran (pencairan anggaran).

Levey dan Loomba dikutip Azwar (2006: 22) mengemukakan bahwa suatu perencanaan yang baik adalah yang mempunyai kriteria antara lain harus: (1) mempunyai tujuan yang jelas; (2) mengandung uraian yang lengkap tentang segala aktivitas yang akan dilaksanakan, yang dibedakan pula atas aktivitas pokok serta aktivitas tambahan; (3) dapat menguraikan pula jangka waktu pelaksanaan setiap aktivitas ataupun keseluruhan aktivitas yang akan dilaksanakan, di mana suatu rencana yang baik, hendaknya berorientasi pada masa depan bukan sebaliknya; (4) dapat menguraikan macam organisasi yang dipandang tepat untuk melaksanakan 
aktvitas-aktivitas yang telah disusun, harus dijelaskan pula pembagian tugas masingmasing bagian atau individu; mencantumkan segala hal yang dipandang perlu untuk melaksanakan aktivitas-aktivitas yang telah disusun, seperti macam tenaga pelaksananya, besarnya dana dan sumber dana yang diperkirakan ada; (6) mempertimbangkan segala faktor yang mempengaruhi atau diperkirakan mempengaruhi rencana tersebut, sehingga menjadi jelas apakah rencana tersebut dapat dilaksanakan atau tidak; (7) dibuat dengan berpedoman pada sistem yang dimiliki dan orientasi penyusunannya pada keseluruhan sistem tersebut, bukan terhadap masingmasing individu pelaksananya; (8) memiliki unsur fleksibilitas artinya sesuai dengan situasi dan kondisi yang dihadapi, sedemikian rupa sehingga pemanfaatan sumber dan tata cara dapat diatur dengan baik dalam rangka mencapai tujuan yang telah ditetapkan; (9) mencantumkan dengan jelas standar yang dipakai untuk mengukur keberhasilan atau kegagalan yang akan terjadi. Jadi suatu rencana dapat menguraikan pula mekanisme kontrol yang akan dipergunakan; dan (10) dilaksanakan terus-menerus, artinya hasil yang diperoleh dari perencanaan yang sedang dilakukan, dapat dipakai sebagai pedoman untuk perencanaan selanjutnya.

Menurut Setiawan (2013: 44), tahapan-tahapan dalam membuat rencana anggaran sektor publik, yaitu meliputi (1) penetapan strategi organisasi (visi dan misi), (2) pembuatan tujuan, (3) penetapan aktivitas, dan (4) evaluasi dan pengambilan keputusan.

\section{Penatausahaan Keuangan Daerah}

Sesuai Peraturan Pemerintah Nomor 58 Tahun 2005 dan berdasarkan Permendagri Nomor 13 Tahun 2006 tentang Pedoman Pengelolaan Keuangan Daerah, penatausahaan keuangan daerah merupakan bagian yang tak terpisahkan dari proses Pengelolaan Keuangan Daerah. Penatausahaan keuangan daerah mencakup hal-hal sebagai berikut: (a) asas umum penatausahaan keuangan daerah; (b) pelaksanaan penatausahaan keuangan daerah; (c) penatausahaan penerimaan; (d) penatausahaan pengeluaran; dan (e) peranan penatausahaan keuangan daerah dalam meningkatkan efektivitas pelaksanaan APBD.

Menurut Anthony dalam Maulana (2012: 183) reektivitas adalah hubungan antara keluaran suatu pusat pertanggungjawaban dengan sasaran yang harus dicapai. Efektivitas pelaksanaan anggaran merupakan kesesuaian antara keluaran (output) dengan tujuan yang telah ditetapkan sebelumnya. Untuk dapat melihat efektivitas pelaksanaan anggaran dapat dilakukan dengan cara membandingkan antara anggaran yang telah ditetapkan dengan realisasi dari pelaksanaan anggaran tersebut. Semakin kecil penyimpangan- 
penyimpangan yang terjadi antara anggaran dengan realisasinya maka semakin efektif pula pelaksanaan anggaran. Untuk mencapai efektivitas pelaksanaan anggaran diperlukan suatu pengelolaan yang memadai. Pengelolaan meliputi perencanaan, pelaksanaan dan pengawasan dimana ketiga hal tersebut saling berkaitan satu sama lain.

Tata cara atau prosedur pelaksanaan sistem penatausahaan keuangan daerah sangat penting dalam penyelenggaraan Pemerintahan di Daerah mengingat perkembangan volume kegiatan dari tahun ke tahun terus meningkat, yaitu dengan melakukan:

a. Mempersiapkan buku-buku untuk pencatatan kegiatan pelaksanaan anggaran belanja.

b. Pencatatan dalam Buku Kas Umum dan Buku Kepala/Buku Pembantu.

c. Pengolahan tanda-tanda bukti untuk menyusun Surat Pertanggungjawaban.

d. Penyimpanan uang dan dokumendokumen.

Untuk menjamin agar kegiatan pembangunan berjalan efektif, efisien, dan bersasaran maka diperlukan Perencanaan Pembangunan Nasional serta keseragaman peraturan yang berlaku guna tercapainya tujuan bernegara dan menghindarkan dari ketimpangan antar wilayah. Ketentuan mengenai sistem Perencanaan Pembangunan Nasional, yang mencakup penyelenggaraan perencanaan makro atau perencanaan yang berada pada tataran kebijakan nasional atas semua fungsi pemerintahan dan meliputi semua bidang kehidupan secara terpadu dalam Wilayah Negara Republik Indonesia diatur dalam UU No. 25 Tahun 2004 tentang Sistem Perencanaan Pembangunan Nasional. Bertolak dari uraian tersebut, maka pengelolaan keuangan daerah berarti mengurus dan mengatur keuangan daerah itu sendiri dengan prinsip-prinsip pengelolaan keuangan daerah, menurut Devas dikutip Setiawan (2013: 279-280) prinsip-prinsip tersebut meliputi tanggung jawab (accountability), mampu memenuhi kewajiban keuangan, kejujuran, hasil guna (efectiveness) dan daya guna (efficiency), dan pengendalian.

\section{Penyerapan Anggaran}

Dalam organisasi sektor publik selain untuk meningkatkan cakupan anggaran dan kemanfaatan program tujuan penyerapan anggaran adalah untuk memberikan feedback serta follow up agar di periode-periode berikutnya bisa berjalan lebih baik lagi.

Ada dua jenis laporan realisasi pelaksanaan anggaran, yaitu laporan manajemen yang merupakan laporan taksiran pelaksanaan anggaran dan laporan keuangan disusun/dibuat setelah tahun anggaran berlalu karena harus merupakan angka aktual yang dilengkapi oleh bukti-bukti pendukungnya (Kosasih, 2012: 37).

Laporan manajemen yang merupakan laporan taksiran pelaksanaan 
anggaran, laporan ini masih merupakan angka taksiran (minimal untuk bulan Desember belum ada realisasinya) karena harus disiapkan sebelum tahun anggaran berakhir untuk kemudian dipertanggungjawabkan dalam RUPS akhir tahun sekaligus mengesahkan anggaran tahun berikutnya (anggaran harus sudah ada sebelum tahun anggaran dimulai). Sedangkan laporan keuangan yang disusun/dibuat setelah tahun anggaran berlalu, laporan keuangan ini disiapkan untuk kemudian diaudit oleh auditor akuntan publik atau oleh BPKP bagi BUMN sehingga ada lembaga resmi yang diakui pemerintah untuk memberkan pendapat tentang laporan keuangan tersebut.

Penyerapan anggaran merupakan salah satu tahapan dari siklus anggaran yang dimulai dari perencanaan anggaran, penetapan dan pengesahan anggaran oleh Dewan Perwakilan Rakyat (DPR), penyerapan anggaran, pengawasan anggaran dan pertanggungjawaban penyerapan anggaran. Tahapan penyerapan anggaran ini dimulai ketika Undang-Undang (UU) Anggaran Pendapatan dan Belanja Negara (APBN) disahkan oleh DPR. Dalam rangka terjadinya kesatuan pemahaman serta kesatuan langkah dalam pelaksanaan, pemerintah sebagai pelaksana dari UU APBN selanjutnya menerbitkan Keputusan Presiden (Keppres) tentang Pedoman Pelaksanaan Anggaran Pendapatan dan Belanja Negara sebagai dasar hukum pelaksanaan APBN. Pada saat ini Keppres yang berlaku adalah Keppres Nomor 42 tahun 2002.

Secara teknis penyerapan anggaran dipengaruhi oleh faktor perencanaan anggaran dan uang peresediaan (UP). Perencanaan anggaran tersusun dalam dokumen perencanaan pembangunan daerah. Perencanaan pembangunan daerah ini disusun untuk menjamin keterkaitan dan konsistensi antara perencanaan, penganggaran, pelaksanaan dan pengawasan. Dokumen perencanaan memuat kegiatankegiatan yang diperlukan untuk menghasilkan secara utuh sasaran hasil kinerja pembangunan dalam bentuk kerangka regulasi dan kerangka anggaran yang disebut dengan rencana kerja. Setiap Rencana Kerja menjadi landasan dalam pelaksanaan koordinasi dan monitoring implementasi rencana dalam maksud menghasilkan setiap sasaran hasil kinerja pembangunan

Uang Persediaan (UP) adalah uang muka kerja dengan jumlah tertentu yang bersifat daur ulang (revolving) yang diberikan kepada bendahara pengeluaran hanya untuk membiayai kegiatan operasional kantor sehari-hari yang tidak dapat dilakukan dengan pembayaran langsung. UP hanya digunakan untuk membiayai kegiatan operasional perkantoran yang tidak mungkin dilaksanakan dengan pembayaran secara langsung atau dapat diartikan kegiatan yang 
sifatnya insindentil/mendesak (Amir, 2013: $67)$.

\section{Hipotesis}

Bertolak dari kerangka pemikiran di atas hipotesis dalam penelitian ini dirumuskan sebagai berikut:

1. Perencanaan keuangan berpengaruhi positif dan signifikan terhadap realisasi penyerapan anggaran pada Dinas Pendidikan Kota Tangerang.

2. Penatausahaan keuangan berpengaruh signifikan terhadap realisasi penyerapan anggaran pada Dinas Pendidikan Kota Tangerang.

3. Perencanaan penganggaran dan penatausahaan keuangan secara bersama-sama berpengaruh signifikan terhadap realisasi penyerapan anggaran pada Dinas Pendidikan Kota Tangerang Tangerang.

\section{E. Hasil Penelitian Dan Pembahasan}

\section{Hasil Penelitian}

Hasil uji $t$ hitung pengaruh perencanaan terhadap realisasi penyerapan anggaran, diperoleh skor nilai sebesar 4,407 nilai sig. 0,000 . Sementara itu nilai $t$ tabel untuk dk (78 - $2=76)$ dalam nilai-nilai distribusi $\mathrm{t}$ untuk uji dua pihak taraf signifikan 0.05 menunjukkan skor nilai sebesar 1.665. Artinya $t_{\text {hitung }}(4.407)>t_{\text {tabel }}$ (1.665) atau nilai sig. 0,000<0,05. Dengan demikian, Ho ditolak dan Ha diterima.
Hasil uji t hitung pengaruh penatausahaan keuangan terhadap realisasi penyerapan anggaran, diperoleh skor nilai sebesar 3,938 nilai sig. 0,000 . Artinya $t_{\text {hitung }}$ (3.938) $>\mathrm{t}_{\text {tabel }}(1.665)$ atau nilai sig. 0,000 < 0,05. Dengan demikian, Ho ditolak dan $\mathrm{Ha}$ diterima.

Hasil uji $\mathrm{F}$ atau $\mathrm{F}_{\text {hitung }}$ diperoleh skor nilai sebesar 9,598 dengan probabilitas signifikan 0.05. sedangkan $F_{\text {tabel }}(\alpha=0,05)$ dengan $\mathrm{dk}$ penyebut dan $\mathrm{dk}$ pembilang pada titik $\mathrm{n}=78$ adalah 1.39. Jadi, $\mathrm{F}$ hitung (15.080) $>$ dari $\mathrm{F}$ tabel $(1.45)$ atau dengan nilai sig. $=$ $0,000<0,05$, karena $F_{\text {hitung }}$ lebih besar dari $\mathrm{F}$ tabel maka model regresi dapat digunakan untuk memprediksi realisasi penyerapan anggaran atau dapat dikatakan perlakuan variabel independen perencanaan dan penatausahaan keuangan secara bersamasama berpengaruh terhadap realisasi penyerapan anggaran.

Dari nilai persamaan yang dihasilkan oleh regresi linier berganda dapat dijelaskan sebagai berikut:

Realisasi penyerapan anggaran $=$ $25.078+0.503$ perencanaan penganggaran + -0.051 penatausahaan keuangan. Nilai konstanta sebesar 25.078 menyatakan bahwa jika variabel independen (perencanaan dan penatausahaan keuangan) diabaikan atau bernilai 0 , maka nilai realisasi penyerapan anggaran bernilai sebesar 25.078. Nilai koefisien perencanaan bertanda positif sebesar 0.503, hal ini menunjukkan bahwa jika ada peningkatan perencanaan sebesar 1 
satuan, maka akan meningkatkan realisasi penyerapan anggaran sebesar 0.503 dengan asumsi variabel lain dan konstan diabaikan. Nilai koefisien penatausahaan keuangan bertanda negative sebesar -0.051 , hal ini menunjukkan bahwa jika ada peningkatan penatausahaan keuangan sebesar 1 satuan, maka akan meningkatkan realisasi penyerapan anggaran sebesar -0.051 dengan asumsi variabel lain dan konstan diabaikan.

Hasil perhitungan regresi linier berganda itu memberikan gambaran bahwa arah hubungan antara perencanaan dan penatausahaan keuangan ternyata searah, dimana setiap kenaikan 1 satuan pada variabel perencanaan dan penatausahaan keuangan, maka akan menyebabkan kenaikan terhadap realisasi penyerapan anggaran sebesar 25.530.

Sementara itu dari uji korelasi, diperoleh nilai sebesar 0.451. Koefisien korelasi tersebut perlu dibandingkan dengan nilai-nilai $\mathrm{r}$ tabel product moment, pada taraf signifikan $5 \%$ dengan jumlah sampel $n=78$ menunujukkan skor nilai sebesar 0,220. Jika dibandingkan dengan skor ternyata nilai $r$ hitung $(0,451)>\mathrm{r}$ tabel $(0,220)$, maka Ho ditolak dan Ha diterima. Jadi kesimpulannya ada pengaruh positif perencanaan dan penatausahaan keuangan secara bersamasama terhadap realisasi penyerapan anggaran pada Dinas Pendidikan Kota Tangerang. Nilai koefisien korelasi yang diperoleh sebesar 0,451 , sesuai dengan pedoman interpretasi koefisien korelasi, menurut
Sugiyono (2007: 250), maka interpalnya terletak antara $0,600-0,799$ dengan demikian diketahui bahwa tingkat pengaruh antara perencanaan dan penatausahaan keuangan dengan realisasi penyerapan anggaran adalah termasuk dalam kategori sedang.

Dari uji koefisien determinas diperoleh skor nilai sebesar $20.4 \%$ atau dapat dilihat pada nilai $\mathrm{R}$ Square yang menunjukkan skor nilai sebesar 0.204. Hal ini membuktikan bahwa perencanaan dan penatausahaan keuangan dapat memberikan kontribusi terhadap realisasi penyerapan anggaran pada Dinas Pendidikan Kota Tangerang sebesar $20.4 \%$ dan sebesar $79.6 \%$ masih dipengaruhi oleh faktor lain, seperti anggaran daerah, kebijakan pemerintah dan lain-lain.

\section{Pembahasan}

Pengaruh perencanaan terhadap realisasi penyerapan anggaran pada Dinas Pendidikan. Hasil analisis menunjukkan uji t hitung diperoleh skor nilai sebesar 4,407 nilai sig. 0,000. Artinya $\mathrm{t}$ hitung $(4.407)>\mathrm{t}$ tabel (1.665) atau nilai sig. $0,000<0,05$, maka Ho ditolak dan Ha diterima. sehingga dapat dinyatakan bahwa secara parsial variabel perencanaan berpengaruh signifikan terhadap realisasi penyerapan anggaran pada Dinas Pendidikan Kota Tangerang. Hasil penelitian ini bertolak belakang dengan penelitian yang dilakukan oleh Haykal (2007) tentang Analisis peran dan fungsi 
SKPD dalam Pengelolaan keuangan daerah serta pengaruhnya terhadap kinerja SKPD (studi kasus pada Pemkab Aceh Timur). Hasil penelitian tersebut menyebutkan bahwa secara parsial diketahui bahwa hanya variabel penyusunan anggaran berpengaruh terhadap signifikan kinerja SKPD, sedangkan untuk varabel perencanaan anggaran dan pelaporan anggaran tidak berpengaruh secara signifikan terhadap kinerja SKPD.

Pengaruh penatausahaan keuangan terhadap realisasi penyerapan anggaran pada Dinas Pendidikan. Hasil analisis menunjukkan uji $t_{\text {hitung }}$ diperoleh skor nilai sebesar 3,938 nilai sig. 0,000 . Artinya $t_{\text {hitung }}$ (3.938) $>t_{\text {tabel }}(1.665)$ atau nilai sig. 0,000 < 0,05 , sehingga dapat dinyatakan bahwa secara parsial variabel penatausahaan keuangan berpengaruh signifikan terhadap realisasi penyerapan anggaran pada Dinas Pendidikan Kota Tangerang. Hasil penelitian ini sama dengan Syahrida (2009) tentang Pengaruh Pemahaman Sistem Akuntansi, Pengelolaan Keuangan Daerah terhadap Kinerja SKPD pada pemerintahan Provinsi Sumatera Utara, yang menyebutkan bahwa secara parsial pemahaman sistem akuntansi dan pengelolaan keuangan daerah terhadap kinerja SKPD berpengaruh signifikan.

Pengaruh perencanaan penganggaran dan penatausahaan keuangan secara bersama-sama terhadap realisasi penyerapan anggaran pada Dinas Pendidikan, hasil analisis menunjukkan hasil uji $\mathrm{F}_{\text {hitung }}(15.080)>$ dari $\mathrm{F}_{\text {tabel }}(1.45)$ atau dengan nilai sig. $=0,000<0,05$, artinya dapat dikatakan bahwa perencanaan dan penatausahaan keuangan secara simultan berpengaruh signifikan terhadap realisasi penyerapan anggaran pada Dinas Pendidikan Kota Tangerang. Uji regresi linier berganda $\hat{\mathrm{Y}}=25.078+0.503 .\left(\mathrm{X}_{1}\right)+-0.051 .\left(\mathrm{X}_{2}\right)$, sehingga dapat dinyatakan bila perencanaan dan penatausahaan keuangan lebih ditingkatkan sebesar 1 satuan, maka realisasi penyerapan anggaran menjadi akan meningkat sebesar 25.530. Uji koefisien korelasi (R) diperoleh skor nilai sebesar 0.451 ternyata nilai $r$ hitung $(0,451)>r$ tabel $(0,220)$, skor nilai korelasi 0,451 berada pada interpal koefisien korelasi 0,600-0,799 memiliki tingkat hubungan dalam kategori sedang. Uji koefisien determinasi (KD) diperoleh skor nilai sebesar 20.4\% (R Square 0.204), artinya perencanaan dan penatausahaan keuangan dapat memberikan kontribusi terhadap realisasi penyerapan anggaran pada Dinas Pendidikan Kota Tangerang sebesar $20.4 \%$ dan sebesar $79.6 \%$ masih dipengaruhi oleh faktor lain yang tidak diteliti, seperti anggaran daerah, kebijakan pemerintah dan lain-lain. Hasil penelitian ini sejalan dengan penelitian yang dilakukan James Edward (2015) yang menemukan bahwa perencanaan yang baik sangat membantu tingkat penyerapan anggaran. Selain itu diperlukan pengawasan sejak awal perencanaan agar dapat mendeteksi kemungkinan kegagalan penyerapan 
anggaran lebih dini. Pelaporan juga memiliki peranan penting untuk mengetahui perkembangan penyerapan anggaran. Untuk mempercepat penyerapan anggaran belanja negara maka diperlukan peraturan yang berorientasi pada pemberian kepercayaan pada eksekuif agar dapat lebih fleksibel dalam menggunakan anggaran dengan tetap mengedepankan prinsip efekivitas, efisiensi dan akuntabilitas.

\section{F. Kesimpulan}

1. Perencanaan penganggaran berpengaruh positif dan signifikan terhadap realisasi penyerapan anggaran pada Dinas Pendidikan Kota Tangerang. Artinya anggaran belanja yang direncanakan sesuai dengan kebutuhan instansi baik sumber, alokasi dan pemakaian sumber daya ekonomi direalisasikan sebagaimana mestinya, sekalipun di beberapa hal masih terdapat kelemahan terutama dalam hal penyusunan prosesnya lebih rumit karena perlu menyesuaikan antara usulan dengan anggaran, butuh waktu yang lama agar terjadi kesesuaian dan terkadang usulan yang diajukan tingkat satuan unit kerja melebihi anggaran yang ditetapkan.

2. Penatausahaan keuangan berpengaruh positif dan signifikan terhadap realisasi penyerapan anggaran pada Dinas Pendidikan Kota Tangerang. Artinya pengelolaan anggaran yang digunakan oleh Dinas Pendidikan telah sesuai dengan wewenang yang diberikan, baik dalam aspek keuangan dan kebijakan, serta mampu mengelola pengeluaran keuangan dengan baik sesuai dengan target yang dicapai. Oleh karena itu, selaku entitas pengguna anggaran pemerintah daerah, maka efektivitas pelaksanaan anggaran pada Dinas Pendidikan Kota Tangerang diperlukan suatu pengelolaan yang mengingat mengingat perkembangan volume kegiatan dari tahun ke tahun terus meningkat.

3. Perencanaan penganggaran dan penatausahaan keuangan berpengaruh positif dan signifikan terhadap realisasi penyerapan anggaran pada Dinas Pendidikan Kota Tangerang. Hal ini menunjukkan tingkat keberhasilan Dinas Pendidikan Kota Tangerang dalam membuat suatu perencanaan dan penatausahaan keuangannya telah berjalan efektif sesuai dengan tujuan, meskipun di dalam pelaksanaannya baik perencanaan dan penatausahaan keuangan yang dilaksanakan oleh Dinas Pendidikan Kota Tangerang hanya memberikan kontribusi sebesar 20,4\% terhadap realisasi penyerapan anggaran. Artinya kegiatan pembelanjaan tersebut belum terealisasi secara maksimal sesuai dengan yang telah direncanakan. 


\section{Referensi}

Amir. M. 2013. Penatausahaan Keuangan Daerah, Edisi Ke-3. Jakarta: Rineka Cipta.

Azwar, A. 2006. Pengantar Administrasi, Edisi Ketiga. Jakarta: Binarupa Aksara.

Feriyanto dkk. 2015. Pengantar Manajemen (3 in 1). Kebumen: Medi Tera.

Halim, A.dkk, 2012. Akuntansi Sektor Publik Akuntansi Keuangan Daerah. Edisi 4. Jakarta: Salemba Empat.

Handoko, T. H. 2009. Manajemen. Yogyakarta: BPFE.

James, E.. 2015. Analysis on Ministries, State Organisaions, and Regional Government Low Budget Absorpion. Jurnal Rechts Vinding ISSN 2089-9009.

Keban, Yeremis T. 2008. Perbandingan Administrasi Negara Antara Pemerintahan Pusat dan Daerah Yogyakarta: MAP UGM.

Keputusan Menteri Dalam Negeri No. 59 tahun 2007 tentang Pedoman Pengelolaan Keuangan Daerah.

Keputusan Kepala LAN No.239/IX/6/8/2003 tentang Pedoman Penyusunan Pelaporan Akuntabilitas Kinerja Instansi Pemerintah.

Kosasih, E. dkk. 2012. Manajemen Keuangan-Akuntansi Perusahaan Pelayaran. Edisi Kedua. Jakarta: PT. Raja Grafindo Persada.

Kurniawan, G. 2009. Sistem Pengendalian Intern Laporan Keuangan. Jurnal. Padang: Fakultas Ekonomi Universitas Negeri.

Laporan Keuangan Dinas Pendidikan dan Kebudayaan Kota Tangerang Tahun Anggaran 2016.

Mardiasmo. 2009, Akuntansi Sektor Publik, Yogyakarta: ANDI.

Mardiasmo. 2012. Perpajakan Edisi Revisi 2008. Yogyakarta ; Andi Publisher.

Maulana, A. 2012, Sistem Pengendalian Manajemen, Jakarta: Salemba Empat.

Munandar. M. 2005. Budgeting: Perencanaan Kerja, Pengkoordinasian Kerja dan Pengawasan Kerja. Yogyakarta: BPFE.

Muninjaya, AAP. 2004. Pengantar Manajemen. Jakarta: Penerbit Buku Kedokteran EGC: 220234.

Pasolong. 2011. Ilmu Administrasi dan Pemerintahan, Malang; YA3.

Pedoman Penyusunan Pelaporan Akuntabilitas Kinerja Instansi Pemerintah. Jakarta: Lembaga Administrasi Negara RI.

Peraturan Pemerintah No. 58 tahun 2005 tentang Pengelolaan Keuangan Daerah.

Peraturan Menteri Dalam Negeri Republik Indonesia Nomor 64 Tahun 2013 tentang Penerapan Standar Akuntansi Pemerintahan Berbasis Akrual Pada Pemerintah Daerah.

Pinto, S. 2013. Tinjauan dari Regulasi Pengelolaan Keuangan Daerah. Yogyakarta: CV. Andi Offset. 
Rahayu, S. 2011. Penyusunan Anggaran. Edisi Pertama. Jakarta: Salemba Empat.

Riadi. E. 2016. Statistika Penelitian (Analisis Manual dan IBM SPSS). Yogyakarta: Andi Offset.

Rizki, A. Metode Penelitin Deskriptif, Yogyakarta: Andi Offset.

Setiawan, A. 2013. Akuntansi Sektor Publik: Tahapan-tahapan Penyusunan Anggaran. Jakarta: Salemba Empat.

Siagian. S.P. 2008. Filsafat Administrasi. Jakarta: PT. Gunung Agung.

Standar Akuntansi Pemerintaha (SAP). 2012. Peraturan Pemerintah Republik Indonesia Nomor 71 Tahun 2010. Bandung: Fokusmedia.

Sugiyono. 2014. Metode Penelitian Manajemen. Pendekatan Kuantitatif, Kualitatif, Kombinasi (Mixed Methods), Penelitian Tindakan (Action Research) dan Penelitian Evaluasi. Cetakan Ke-2. Bandung: Alfabeta.

Suprayogi, Y. 2011. Administrasi Publik: Konsep dan Perkembangan Ilmu di Indonesia. Yogyakarta. Graha Ilmu.

Syafri. Wirman. 2012. Studi Tentang Administrasi Publik. Jakarta: Erlangga.

Undang-Undang No. 23 Tahun 2014 tentang Pemerintahan Daerah.

Undang-Undang Nomor 33 Tahun 2004 tentang Perimbangan Keuangan antara Pemerintah Pusat dan Daerah. 